\title{
Reflection on Labor Standard's Linkage to International Trade
}

\author{
Yu-hong $\mathrm{Xu}^{1}$ \\ ${ }^{1}$ School of Economics, Shandong Normal University, Jinan, Shandong, China \\ Correspondence: Yu-hong Xu, School of Economics, Shandong Normal University, Jinan, Shandong, China. \\ E-mail: 249347552@qq.com
}

Received: January 13, 2016

Accepted: January 29, 2016

Online Published: February 25, 2016

doi:10.5539/ijef.v8n3p165

URL: http://dx.doi.org/10.5539/ijef.v8n3p165

\begin{abstract}
Developed countries proposed to link labor standard up to the international trade, which was based on profound economic and social foundation. On this issue, there is a fundamental difference between developed and developing countries: the developed countries think that the low labor standards in the developing countries are a reflection of social dumping, while the developing countries consider labor standard's linkage to the international trade as an embodiment of trade protectionism in developed countries. Nevertheless, the developed countries still take various measures to promote labor standards in the international trade and this trend tends to be intensified. The ultimate goal of developed countries is to integrate labor standards into the WTO multilateral trading system, and developing countries must face this reality.
\end{abstract}

Keywords: labor standards, social dumping, free trade agreement, voluntary labor standard

\section{Introduction}

In the context of economic globalization, labor standard tends to be internationalized from a domestic issue and becomes a hot topic in the disputes between developed and developing countries. There is a fundamental difference in whether the labor standard should be linked up with international trade through WTO mechanism. Developing countries such as China are often accused of "social dumping" because of their low labor standards, while they refuse to relate labor standards to international trade. Nevertheless, the developed countries still take various measures to promote labor standards in the international trade. For the developing countries, this has become a practical issue that cannot be avoided.

\section{Literature Review}

With the development of economic globalization, the studies of Labor Standard's Linkage to International Trade are paid more attention both at home and abroad. The researches focus on two aspects: one is whether the labor standards should be linked to international trade, the other is how to link.

\subsection{Whether the Labor Standards Should Be Linked to International Trade}

As for the issue, there is a fundamental difference between developed and developing countries. Dani Rodrik (1997) pointed out that many people in developed countries worried that economic globalization would lead to developed countries "Race to the Bottom" and proposed that a unified international labor standard should be developed in trade agreements. Some NGOs also believe that low labor standards in developing countries are "social dumping", which is an act of unfair competition. While development economist Bhagwati argue that linkage of labor standard to the international trade is an embodiment of trade protectionism promoted by developed countries. He was opposed to draw up "social dumping" clause in WTO. Chinese scholars are also hold this view. Wu Gang (2006) pointed out that the linkage between labor standards and international trade was essentially a new kind of trade protectionism. Zhou Peng (2004) built a model on evolution path of labor standards in developing countries to refute the theory of "social dumping".

\subsection{How to Link Labor Standards and International Trade}

Although there have been severe debates on the issue of connecting international trade and labor standards into WTO frame, the developed countries still take various measures to promote labor standards in the international trade. Roman Grynberg and Veniana Qalo (2006) addressed the development and enforcement of labor standards in US and EU FTAs and non-reciprocal preferential trading arrangements. Wang (2006) and, Liu and Rao (2008) discussed the models of connecting international trade and labor standards. Some scholars have studied on 
specific models, such as SA8000. In recent years, the labor standards in free trade agreements are increasingly concerned. Chen (2014) Studied on International Core Labor Standards in Multi and Bilateral Trade Agreements and found that U.S. and EU were active to incorporate labor issues into regional free trade agreements, which thereafter formed "NAFTA mode" and "EU mode". Liu and Cai (2015) and Zheng (2013) discussed the labor standards in TPP negotiation.

From the existing researches, the linkage between labor standards and international trade is usually regarded as an economic problem and lack the analysis from the perspective of political economy. As for the models of connecting labor standards and international trade, the current researches concentrate on a model or several models and seldom focus on the development trend. So this paper will study on the linkage between labor standards and international trade from the perspective of political economy and analyze the development trend systematically to provide a reference for developing countries.

\section{Method}

\subsection{Method of Political Economy Analysis}

Based on the different status of the developed countries and the developing countries in the international trade system, this article analyzes the realistic basis of connecting labor standards and international trade from the perspective of political economy. In essence, the connection is not only an economic problem, but also a political issue.

\subsection{Method of Comparative Analysis}

With regard to the issue whether the labor standards should be linked to international trade, the article compares the different understanding between the developed counties and the developing counties. The developed countries think that the low labor standards in the developing countries are a reflection of social dumping, while the developing countries consider labor standard's linkage to the international trade as an embodiment of trade protectionism in developed countries.

\section{Discussion}

\subsection{Realistic Basis for Labor Standard's Linkage to International Trade}

Developed countries proposed to link labor standards up to the international trade, which meant that the labor standard has evolved into an issue of trade relations and political relations from a simple problem on labor relations. This is based on profound economic and social basis.

4.1.1 The Impact of Low Labor Costs in Developing Countries on the Market and Employment in Developed Countries

As developing countries begin to engage in the economic globalization, their export trade develops rapidly due to their cheap labor and price advantage of low-end products, which causes a great shock to the market and employment in developed countries. In the meantime, attracted by the low labor costs in developing countries, some multinational companies choose to transfer their investment into the developing countries, which further reduce the employment opportunities in developed countries. Developed countries like Europe and the United States blame this situation on the low labor standards in developing countries. Therefore, when implementing the liberalization of international trade, a unified international labor standard should be developed in trade agreements, and the trade that fails to meet the international standard should be restricted.

\subsubsection{Intensification of Social Problems and Labor-Capital Contradiction}

Under the background of the integration of the world economy, social problems and labor-capital contradiction are increasingly prominent. It is a very common phenomenon in many countries that the economic development is at the expense of the capital tilt and the interests of works. The intensified capital rights and the abused and deprived labor rights have broken the relative balance of international labor-capital relations formed many years after the Second World War. The intensified labor-capital contradiction and the reduced labor status urge labor organizations to actively advocate labor standard's linkage to the international trade. For example, AFL-CIO in the United States considers that, in the context of economic globalization, as WTO does not enforce minimum labor standards, the workers are being exploited in the global market. The most efficient way to protect labor rights is to reward or punish a certain product through the global trading system.

\subsubsection{The Rise of Civil Society Movements in Developed Countries}

After the end of the Cold War, the civil society movements developed rapidly. Especially in developed countries, the so-called moral consumption and investment activities initiated by civil society groups have attracted more 
and more attention from ordinary consumers and investors. Since 1990s, the consumers in civil activities required that the manufacturers must shoulder social responsibilities, so they launched the initiative of ethical trade, which forced the multinational companies to implement minimum labor standards in their own factories and their suppliers in developing countries. At the same time, moral considerations and social responsibilities have increasingly become the important factors that affect the investment decisions of investors. Adam Candy, the Head of Social Investment Group Shareholder Initiative in the United States, pointed out that the investors pay the most attention to the indicators of labor and environmental protection when evaluating the social consciousness of a company.

Thus, it can be seen that there are a lot of advocates in developed countries who support the linkage of labor standard to the international trade no matter from the perspectives of the government and labor organizations or from the angles of consumers and investors. They do this not only to protect the trade, but also to safeguard the labor interests in the case that the workers' rights are being increasingly neglected and infringed.

\subsection{North-South Division on Labor Standard's Linkage to the International Trade}

4.2.1 Developed Countries: The Theory of Social Dumping Is the Theoretical Basis for the Labor Standard's Linkage to the International Trade

The human rights and labor organizations in the Western countries think that, as the labor protection standards in developing countries are lower than those in developed countries, the former's export costs are also significantly lower than those of the latter, therefore, the developing countries are high competitive in terms of exports. However, the exports of developing countries are at the expense of labor rights, which is a kind of social dumping and has caused a considerable negative influence on the domestic economy of developed countries. Firstly, the domestic manufacturing industry in developed countries has been exposed to the unfair competition of low labor standards from developing countries. Benefiting from their cheap labor, developing countries export a lot of labor-intensive products to developed countries, which expose some unskilled workers in developed countries to the risks of salary reduction and even unemployment. Secondly, attracted by the low labor costs in developing countries, some multinational companies divert their investments into developing countries, which further reduce the domestic income and employment opportunities of developed countries. Thirdly, developed countries profess that due to the above effects, they had to take some measures to reduce their domestic labor standards so as to deal with the competition from developing countries, thus resulting in the loss of national welfare; that is, they compete with the low standards.

In addition, developed countries consider the labor standard as the most fundamental human right as well as a right that should be pursued by all human beings. Labor standards including prohibiting the use of child labor, freedom of association, organizing unions, freedom of collective bargaining and boycott of forced labor are unrelated to economic development phases but serve as the core standards that reflect human rights. It is immoral and unfair for developing countries to develop their export business based on low labor standards, and the international society should boycott such trend. Meantime, the provisions on core labor standards should be included in WTO mechanism, and the countries that do not meet the labor standards should be punished with trade sanctions. Thus, the workers will be protected just like the capital and intellectual property.

4.2.2 Developing Countries: The Linkage of Labor Standard to the International Trade Is an Embodiment of Trade Protectionism

Developing countries point out that the so-called social dumping is just a new excuse of trade protectionism proposed by developed countries, which forms a new kind of trade barrier-blue barrier. The problem of labor standards should be handled by international organizations like International Labor Organization but not by multilateral trade organizations, not to mention its relation to trade sanctions.

The economist Stephen Grasberg analyzed the Achilles' heel of social dumping theory from the basic principles of the trade. According to David Ricardo's theory of comparative advantage, the international differences in labor costs do not prevent the mutually beneficiary trade. Those who fear that the high-wage countries cannot compete with the low-wage countries often confuse the fundamental differences in comparative advantage and absolute advantage. In accordance with the traditional trade theories, the overall difference (absolute advantage) of productivity determines the salary, while the productivity and cost variation (comparative advantages) of specific departments decide the trade pattern. If low salary reflects low labor productivity, all advantages resulting from the employment of low-wage labor will be offset. Low salary may be a result of low labor productivity and poverty but not an independent source of international comparative advantage. Besides, influenced by the differences in economic development level and national culture, the selection of labor standards also differs. Low labor standard and low wage largely reflect the surplus of unskilled workers in 
developing countries and the reality of low labor productivity. Some practices that forcibly intervene in the labor market may not improve the conditions of labor market. Compared with manually stipulated wage and welfare level, to implement the trade and labor market policies that help to promote high-speed growth will be more effective in improving income level.

The US economist Bhagwati organized and drafted the famous Statement of Intellectuals and Non-governmental Organizations from the Third World on Objection to Linkage. He refuted the social clauses and the linkage of WTO to labor issues proposed by some social groups in developed countries on behalf of developing countries and considered they essentially reflect the protectionism of developed countries. The Statement analyzed and pointed out that the initiative of integrating social clauses into WTO protocol was a result of the alliance of two kinds of groups: the first kind of groups are the protectionist groups with strong political power whose aim is to hold back the investments into developing countries and reduce their product competiveness by improving the production costs in these countries; the second kind of groups are the organizations driven by morals such as Human Rights Organization whose aim is to promote the enhancement of labor standards in foreign countries. Unlike the first kind of groups, the second kind of groups do not advocate protectionism, but their requirement of adding social clauses goes to a wrong direction. The promotion of moral goals should not depend on trade but a more positive approach should be taken to tackle this situation.

In essence, all countries aim to protect their own economic interests in the international trade competition. Objectively speaking, both developed countries and developing countries do not really look at the linkage of labor standards to the international trade from a fair and rational perspective. Taking themselves as the reference objects, developed countries consider the low labor standards in developing countries as the social dumping behavior that impedes the world's free development and the fair international competition without taking into consideration whether the international labor standards have exceeded the economic development level of the developing countries, while the developing countries blindly refute the developed countries, fully repudiate the linkage of international standards to the international trade and see it as a new trade barrier without taking into account whether the domestic labor standards lag behind the domestic economic development level. Both of them are biased.

\subsection{The Development Trend of Linking Labor Standards to the International Trade in Developed Countries}

Although developing countries are firmly opposed to the linkage of labor standards to the international trade, developed countries still take various measures to promote labor standards in the international trade. Seeing from the practices of the European and American countries, the following three development trends are mainly presented.

\subsubsection{The Implementation of Unilateral, Bilateral and Multilateral Measures}

Before the establishment of WTO, the linkage of labor standards to the international trade is mainly reflected as the unilateral measures taken by developed countries. As early as the end of the 19th century, the United States took the lead in banning the export of products made by prisoners. In 1930, the US Tariff Act made it clear that the products manufactured by prisoners through forced labor are prohibited to enter the US market. The US Trade Act revised in the 1974 established the principles of GSP and they advocated to provide non-mutual preferential tariffs for underdeveloped countries. However, the amendment of 1984 required that the beneficiary countries should ensure that the workers enjoy the internationally recognized rights: no child labor can be employed; no forced labor is allowed; the workers have the freedom of forming an association and collective bargaining; the minimum wage standard and occupational safety and health standards should be met, or the relevant benefits will be cancelled. In 1988, the US government revised Article 301 of the Omnibus Trade and Competitiveness Act and for the first time classified the behavior of continuous denial of workers' rights as the unreasonable foreign trade and would adopt import restrictions on it.

After WTO was established, developed countries have been trying to integrate labor standards into the multilateral trading system, advocated to introduce the social clauses into the international trade agreements and added labor provisions to the multilateral trade agreements. However, they failed as the developing countries were firmly opposed to these measures. In this situation, the developed countries led by the United States shifted their attention to the free trade agreements and attempted to actively import labor standard terms into them, forming "NAFTA model" and "EU model". Starting from the North American Free Trade Agreement that took effect since January 1, 1994, the United States has introduced for many times the labor standard issues into the bilateral or multilateral free trade agreements signed with their partners. In the process of its expansion to the east, EU also successfully incorporated the labor standards into the negotiation issues when conducting the membership negotiations with the 10 central and eastern European countries in May, 2004. Labor standard was 
also an important topic in the negotiations of TPP and TTIP. Even the Labor Cooperation Memorandum of Understanding was attached to the Sino-New Zealand Free Trade Agreement, the first free trade agreement signed by China with developed countries. Thus, it can be seen that the free trade agreements have become an important tool for developed countries to promote the labor standards.

\subsubsection{From the Top-Down National Enforcement to the Bottom-Up Folk Promotion}

The traditional models that enforce labor standards by means of state power have their own characteristics, but they are severely limited in terms of the application scope and therefore have limited effects. Since 1990s, with the popularity of consumer movements and the implementation of corporate social responsibility movements, a bottom up folk event called Voluntary Labor Standards emerged and played an increasingly important role.

The voluntary labor standards are mainly expressed as corporate code of conduct. With the Universal Declaration of Human Rights developed by the United Nations and the Fundamental ILO Conventions as the blueprints, the companies promise to undertake social responsibilities, abide by the relevant laws of the invested countries, protect the worker's rights, improve the working conditions and require its contractors and subcontractors to follow the same production norms as well. From the perspective of mode of operation, corporate code of conduct can be divided into internal code and external code. The internal code is formulated and implemented by the enterprise itself. Generally, the multinational companies will check the factory before placing an order and regularly recheck it. However, the enterprise's self-discipline alone is not convincing, so the external code comes into being. That is, an independent third party certification body is introduced for review and supervision in accordance with uniform standards. SA8000 is the most famous one. According to the annual report of SAI2010, 2,478 companies from 65 countries have been certified by SA8000, and the number of the workers employed has reached 1,421,035. In November 2010, ISO officially published Social Responsibility Guidelines (ISO26000), which involved human rights and labor, suggesting that the influence of voluntary standards has been further expanded.

In addition, some NGOs that paid attention to labor standards also proposed to add social label to the products. The social label is a label stamped on products to indicate whether the manufacturing and processing processes meet the labor standards. The consumers can choose whether to buy these products in accordance with their morality. Thus, the manufacturers and distributors are urged to abide by the established social norms. The University of Maryland conducted three social surveys in 1995, 1996 and 1999, the survey results showed that more than $75 \%$ consumers considered whether the products manufacturing process meets the labor standards as one of the criteria for their purchase of these goods. Besides, about $76 \%$ consumers expressed that they were willing to pay another 5 USD for a 20 USD shirt that complies with the labor standards.

\subsubsection{The Expansion of Labor Standards from the Trade Sector to Other Fields Like Investment}

In 1985, the United States amended the regulations of overseas private investment corporation, which was an autonomous body belonging to the State Department. It mainly provides investment insurance or direct loans for those American businessmen who invest in developing countries and emerging markets to ensure that the American investors will be compensated when social upheaval, revolution or nationalization occurs or when the currency is inconvertible. The Amendment stipulated that the overseas private investment corporation only provides political risk insurance for those invested projects of the countries that are taking measures and implementing international labor standards.

In addition, the United States also linked labor standards up to the foreign aid. In 1993, the United States amended the Foreign Aid Funding Bill and banned the United States from providing assistance in the following circumstance: The aid will be used for the foreign countries to establish export processing center in the designated area, and the national laws of taxation, tariff, labor, environment and safety are not well implemented or are not implemented at all.

\section{Conclusions}

To sum up, the international labor standards are playing an increasingly important role in the international trade through a variety of means beyond WTO. In the long run, although there is a fundamental difference in the linkage of labor standards' to the international trade between developed and developing countries, it is an inevitable trend that the labor standards will be linked up to the international trade under the framework of WTO as developed countries still dominate the formulation of rules for international trade and multilateral trade. Developing countries should face this reality and conduct reasonable institutional arrangements in terms of the contents and ways of implementation of labor standards, thereby promoting the scientific linkage of labor standards to the international trade. 


\section{References}

Stephens, S. G. (1997). Are International Labor Standards Needed to Prevent Social Dumping. Finance \& Development, 12, 20-23. Retrieved from http://www.imf.org/external/pubs/ft/fandd/1997/12/pdf/golub.pdf

Roman, G., \& Veniana, Q. (2006). Labor Standards in US and EU Preferential Trade Arrangements. Journal of World Trade, 4, 619-654.

Xixia, L. (2015). The Development Trend of Labor Standards in Free Trade Agreements. Global Law Review, 1, 165-175.

Zhiyang, C. (2014). Study on International Core Labor Standards in Multi and Bilateral Trade Agreements. Journal of International Trade, 2, 56-64.

Lizhen, Z. (2013). On the Issue of Labor Standard in TPP Negotiation. International Economics and Trade Research, 9, 107-118.

Peng, Z. (2004). The Evolution Path of Labor Standards in Developing Countries_-An Economic Argument against the Accusation of "Social Dumping". Economic Research Journal, 10, 94-103.

Kai, C. (2002). WTO, Labor Standards and Labor Interests Safeguard. Social Sciences in China, 1, 126-134.

Yong, W. (2008). Political Economy of International Trade. Bei Jing, BJ: China Market Press.

\section{Copyrights}

Copyright for this article is retained by the author(s), with first publication rights granted to the journal.

This is an open-access article distributed under the terms and conditions of the Creative Commons Attribution license (http://creativecommons.org/licenses/by/3.0/). 